\title{
Serious ophthalmological complications in the Ehlers-Danlos syndrome
}

\author{
PETER BEIGHTON \\ Division of Medical Genetics, The Johns Hopkins Hospital, Baltimore, Md
}

The main features of the Ehlers-Danlos syndrome (EDS) are cutaneous hyperextensibility, articular laxity, and fragility of the tissues. Systemic ramifications may lead to orthopaedic, cardiovascular, and gastrointestinal problems.

Minor ophthalmological changes, including epicanthic folds, strabismus, and myopia are not infrequent, but serious ocular complications are rare. However, there have been a few reports of patients with impaired vision from retinal detachment or displacement of the lens.

The EDS is a generalized disorder of connective tissue, which is usually inherited as a dominant trait. There is some scanty evidence to indicate the existence of an uncommon recessive form, and it is of great interest that the majority of the reports of sight-threatening lesions have pertained to individuals who could well have had this genetic background.

The purpose of this paper is to describe an affected brother and sister who both became blind from bilateral ocular catastrophes. The transmission of the EDS in their kindred was consistent with recessive inheritance of the trait.

\section{Case reports}

Case I, a white male, weighed $6 \mathrm{lb} .3 \mathrm{oz}$. at birth in 1915. Hypermobility of the finger joints was apparent in early childhood, but apart from a tendency to skin-splitting and a moderate myopia, he was quite well until the age of 19 years. He then developed a left-sided hemiplegia, which was attributed to an intracranial bleed, consequent upon a head injury which had occurred 3 weeks previously. Considerable recovery of function took place, but some weakness of the left arm and leg persisted.

At the age of 22 years, 3 years after this event, he was struck in the right eye by a rubber patch from a car tyre. Although the blow was of no great severity, the globe of the eye was ruptured. Primary suture was performed but vision was lost, and the eye was later enucleated and replaced by a prosthesis.

He remained in good health until the age of 51 , when he tripped in his home and banged the left side of his head on the ground. The globe of the left eye was ruptured and although the scleral tear was sutured, he remained blind.

A younger sister also had the EDS, and she too became blind in early adult life (vide infra). His other six sibs were normal, as were his parents and his own four children. There was no known consanguinity, and no other members of the kindred were affected (Fig. I, overleaf).

\section{Examination}

In 1969 he was found to be a thin, tense man, 70 in. tall and weighing $160 \mathrm{lb}$. His elbows, knees, and shins bore hyperpigmented papyraceous scars, and he had considerable extensibility of the skin. The finger and wrist joints were very lax, and he had a moderate increase in the range of movements 


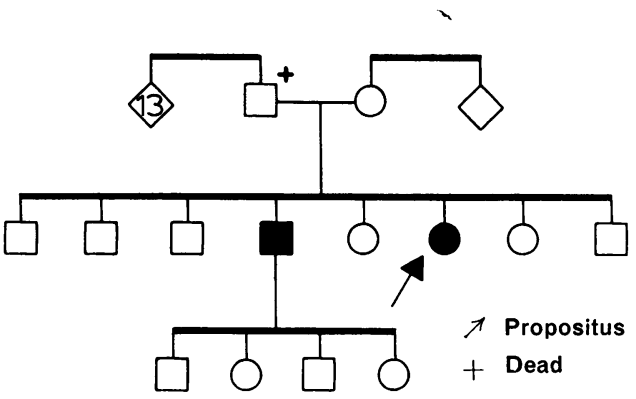

FIG. I Pedigree of the patients' kindred: Affected members shown in black

of his elbow and knee joints. Molluscoid pseudotumours were present over both elbows, and hard subcutaneous spheroids could be palpated in the shins and forearms. The left eye was false, while the right eye was shrunken and deformed, with opacity of the media. Residual signs of a left-sided hemiplegia could be elicited, but the physical examination was otherwise unremarkable.

Case 2, the sister of Case 1, weighed $6 \mathrm{lb}$. at birth in 1924. She had bilateral talipes equinovarus deformities of the feet, which were corrected surgically at the age of 12. A thoraco-lumbar kypho: scoliosis appeared when she was 8 years old, and in spite of treatment by prolonged traction during adolescence, the deformity persisted (Fig. 2). In recent years she has worn a spinal brace for troublesome backache. Frequent dislocations of both shoulders and subluxations of the right patella took place during childhood. These were always easily reducible and the liability to these complications diminished as she reached adult life. Her bony prominences became scarred frome the frequent lacerations which occurred on minor trauma and her shins were discoloured by recurreno bruises (Fig. 3).

She required a transfusion of 3 pints of blood for a haematemesis which occurred when she was $3 \%$ years old. A duodenal ulcer was demonstrated by barium studies at this time, and her continuing dyspepsia was treated with antacids. Melaena occurred 3 years later, but the gastrointestinaf symptoms then resolved. An episode of dysphagia at the age of 44 was attributed to oesophagea $B$ spasm associated with acid reflux and a hiatus hernia. Conservative treatment brought sympto $\overrightarrow{\vec{O}}$ matic relief. When she was in her early forties, cystic masses were removed from each breast a $\bar{B}$ uneventful operations.

Ocular problems began at the age of 6 , when she was given spectacles for severe myopia associated with a divergent strabismus of the right eye. Episodes of visual disturbance led to the diagnosis op. congenital glaucoma when she was 27 years old, and in a brief case report, Durhan (1953) mentionedf that she had microcornea and blue sclera. Daily treatment with 2 per cent. pilocarpine kept here intraocular pressure at a normal level, and apart from a minor bilateral visual field loss, she had nó further eye trouble for 10 years.

At the age of 36 , however, she suddenly lost the sight of the left eye. A detachment of the retina was diagnosed and an unsuccessful repair operation was carried out one month later. The surgeon\$ commented upon the fragility of the sclera and the amount of bleeding which occurred during this: procedure.

In the following year, detachment of the right retina took place. Repair by light coagulation was successful, but a further detachment occurred 6 months later. Surgical intervention did not bring about any improvement, and she subsequently remained totally blind.

\section{Examination}

In 1969 she was found to be a good-natured intelligent blind lady, 64 in. tall and weighing 1 зo lb零 A marked thoraco-lumbar kyphoscoliosis was present and her feet and breasts bore operation scars ${ }_{0}$ She had scarring, articular laxity, and cutaneous hyperextensibility which resembled the stigmatab borne by her brother, both in distribution and in degree. Her left eye was misshapen with and atrophied iris and a dense cataract, while similar but less marked changes were present in the righț eye. No abnormality was detected in any other system. 


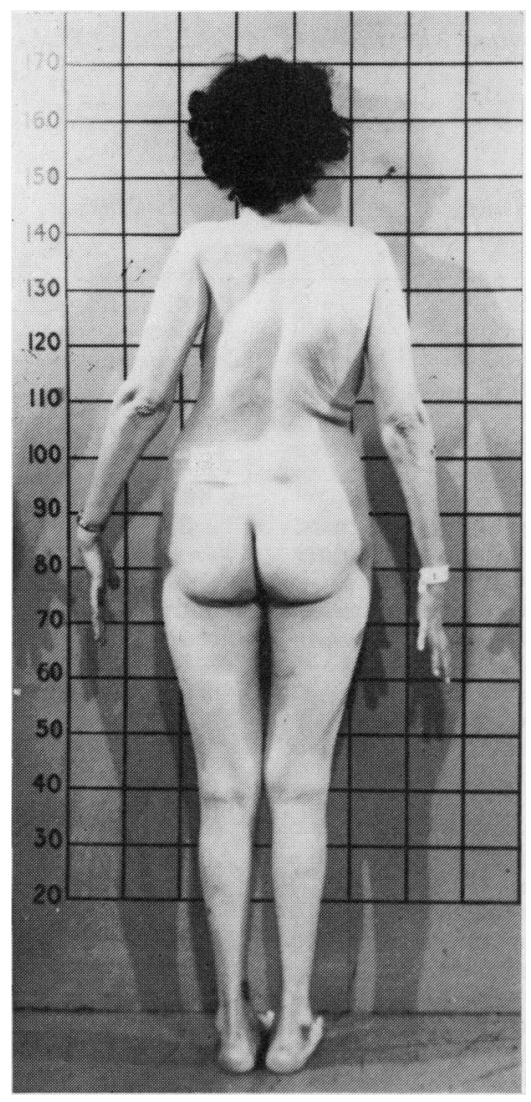

FIG. 2 Case 2. Thoraco-lumbar kyphoscoliosis

FIG. 3 Case 2. Wide hyperpigmented papyraceous scars nver bony prominences of the legs

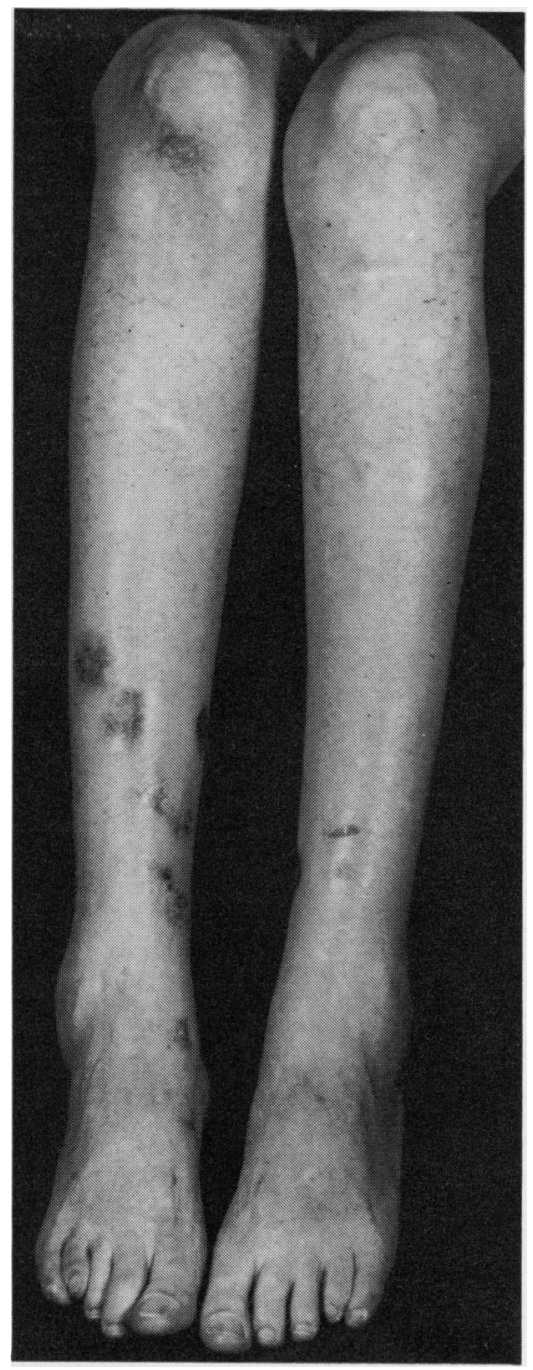

There is no doubt that these two patients had the typical cutaneous and articular stigmata of the EDS, in a moderate degree, and it is of great interest that major ophthalmic calamities, leading to total blindness, occurred in this brother and sister. It may also be significant that both of them initially had myopia, while none of their relatives had any ocular problems.

Although minor ophthalmological abnormalities are common in the EDS, major ocular complications are very infrequent. In a series of 100 affected patients, 27 had epicanthic folds, seven had blueness of the sclera, seven had strabismus, and eight had myopia, while redundant skin on the upper eyelids, ease of eversion of the upper lid (Méténier's sign), and widely-spaced eyes were frequently encountered. None of the patients in this series had any serious ophthalmological lesions (Beighton, ig68a). 
Table Previous reports of serious ophthalmological complications in patients with the Ehlers-Danlo syndrome

\begin{tabular}{|c|c|c|c|c|c|c|}
\hline \multirow[b]{2}{*}{ Authors } & \multirow[b]{2}{*}{ Date } & \multicolumn{2}{|c|}{ Patient } & \multirow[b]{2}{*}{ Ocular lesion } & \multirow[b]{2}{*}{ Family history } & \multirow[b]{2}{*}{ Comment } \\
\hline & & & $\begin{array}{c}\text { Age } \\
(y r s)\end{array}$ & & & \\
\hline Thomas and others & 1953 & F & 2 & $\begin{array}{l}\text { Blue sclera } \\
\text { Keratoconus } \\
\text { Abnormal scleral fragility } \\
\text { Corneal damage on minor } \\
\text { trauma }\end{array}$ & $\begin{array}{l}\text { Brother affected } \\
\text { Parents normal } \\
\text { but consanguineous }\end{array}$ & \\
\hline $\begin{array}{l}\text { Bossu and } \\
\text { Lambrechts }\end{array}$ & 1954 & F & 19 & $\begin{array}{l}\text { Blue sclera } \\
\text { Myopia } \\
\text { Right retinal detachment } \\
\text { and proliferating retinitis } \\
\text { Left macular degeneration } \\
\text { and spontaneous vitreous } \\
\text { haemorrhage }\end{array}$ & $\begin{array}{l}12 \text { sibs } \\
2 \text { affected with } \\
\text { EDS } \\
\text { Parents and other } \\
\text { members of the } \\
\text { kindred were } \\
\text { normal }\end{array}$ & \\
\hline $\begin{array}{l}\text { Cordella and } \\
\text { Vinciguerra }\end{array}$ & 1966 & $\mathbf{M}$ & 30 & $\begin{array}{l}\text { Blue sclera } \\
\text { Right retinal detachment } \\
\text { Left displacement of lens, } \\
\text { with iridodonesis }\end{array}$ & $\begin{array}{l}8 \text { sibs } \\
2 \text { affected with } \\
\text { EDS } \\
\text { Parents normal } \\
\text { but consanguineous }\end{array}$ & \\
\hline $\begin{array}{l}\text { Durham } \\
\text { McKusick } \\
\text { Pemberton and } \\
\text { others }\end{array}$ & $\begin{array}{l}1953 \\
1.966 \\
1966\end{array}$ & $\mathbf{F}$ & & $\begin{array}{l}\text { Blue sclera } \\
\text { Myopia } \\
\text { Bilateral retinal } \\
\text { detachment } \\
\text { Fragile ocular tissue }\end{array}$ & $\begin{array}{l}\text { Affected brother } \\
\text { (Case I) } \\
6 \text { normal sibs } \\
\text { Normal parents }\end{array}$ & $\begin{array}{l}\text { Case } 2 \text { in } \\
\text { present } \\
\text { paper }\end{array}$ \\
\hline Thomas and others & 1952 & $\mathbf{M}$ & 48 & $\begin{array}{l}\text { Dislocated lenses } \\
\text { Fragile ocular tissues at } \\
\text { operation }\end{array}$ & & $\begin{array}{l}\text { Probably } \\
\text { not true } \\
\text { EDS }\end{array}$ \\
\hline Frieden and others & 1962 & $\mathbf{M}$ & 46 & $\begin{array}{l}\text { Retinal detachment } \\
\text { Died from ruptured aortic } \\
\text { valve cusp }\end{array}$ & Affected children & $\begin{array}{l}\text { Probably } \\
\text { not true } \\
\text { EDS }\end{array}$ \\
\hline $\begin{array}{l}\text { Pemberton and } \\
\text { others }\end{array}$ & 1966 & $\mathbf{M}$ & $4^{2}$ & $\begin{array}{l}\text { Retinal detachment } \\
\text { Died from dissected aorta }\end{array}$ & Affected children & $\begin{array}{l}\text { Probably } \\
\text { same con- } \\
\text { dition as } \\
\text { Frieden's } \\
\text { case }\end{array}$ \\
\hline
\end{tabular}

There have been very few reports of grave ocular complications in affected patientso (Table). Thomas, Neimann, Cordier, and Algan (1963) treated a 2-year-old girl whos suffered corneal damage after a minor blow to the head. They noted that she had blue sclera, keratoconus, and undue scleral fragility. Her brother also had the EDS and herN parents, who were normal, were consanguineous. Bossu and Lambrechts (1954) describech an affected 19-year-old girl, who had a detached retina and proliferating retinitis in the्్ right eye and macular degeneration and spontaneous vitreous haemorrhage in the left 0 She had twelve sibs, two of whom showed the EDS. Her parents and the other members of the kindred were normal, and there was no consanguinity. Cordella and Vinciguerrap (1966) reported a 30 -year-old man, with the typical stigmata of the EDS, who had thin blue sclera, a right-sided retinal detachment, and displacement of the lens of the left eye His eight sibs were normal, while two others had been stillborn. His parents were firs cousins. In view of their family histories, it is possible that each of these patients inheritedo the EDS as a recessive trait. 
Durham (1953), Pemberton, Freeman, and Schepens (1966), and McKusick (1966) all mention Case 2 of the present report, but there do not seem to be any other descriptions of serious ocular lesions in individuals with the genuine EDS. Exophthalmos due to an intracranial arterio-venous fistula was described by François, Woillez, Warrot, and Maillet (1955) and similar events have been reported by Graf (1965) and Bannerman, Graf, and Upson (1967). This complication has a vascular rather than an ocular basis, and represents a further uncommon complication of the syndrome.

Thomas, Cordier, and Algan (1952) discussed a 48-year-old man with dislocated lenses, in whom corrective surgery was made difficult by the fragility of the ocular tissues. No members of his kindred were similarly affected. Frieden, Hurwitt, and Leader (1962) reported a 46-year-old man with retinal detachments who died of an aortic lesion, and Pemberton and others (1966) described a large kindred of loose-jointed individuals, in one of whom retinal detachment and dissection of the aorta occurred. However, from the case descriptions, it seems likely that all of these patients had an unusual undelineated connective tissue disorder rather than the true EDS.

From the genetic standpoint, the EDS is usually transmitted as a dominant trait, although an X-linked form has been described (Beighton, 1968b). McKusick (1966) suggested that the EDS might be heterogeneous, and Barabas (1967) and Beighton, Price, Lord, and Dickson (1968) were able to distinguish several clinically distinct dominant types of the disorder. There is no firm evidence for a recessive form of the EDS, but Capotorti and Antonelli (1966) investigated affected sibs in a kindred with a major degree of consanguinity, while Ronchese (1936), Tobias (1934), and Johnson and Falls (1949) also reported affected offspring of consanguineous marriages. Sporadic cases of the EDS are not uncommon, and while many of them probably represent new dominant mutations, it is possible that some of them are homozygotes for a recessive trait. Similarly, there have been several instances of affected sibs with normal parents. Incomplete penetrance of the gene could account for this finding, but recessive inheritance is another possibility.

The fact that Case i had four normal children, an affected sister, normal parents, and six other normal sibs is suggestive of recessive inheritance. It is remarkable that, in addition to Cases I and 2 above, all three other reported patients with serious ocular complications had pedigrees which were consistent with recessive inheritance.

Genetic heterogeneity has been demonstrated in many familial disorders, and on this basis, there is an adequate precedent for a recessive form of the EDS. If a recessive form of the EDS does indeed exist, it appears that the phenotypic features are those dermal and joint changes which are usually found in the EDS of moderate severity, with the addition of a liability to serious ocular complications. Blueness of the sclera and myopia might be additional features of this uncommon recessive ophthalmological form of the EDS.

\section{Summary}

A brother and sister with the typical cutaneous and articular manifestations of the EhlersDanlos syndrome both lost their sight after ocular catastrophes. Their pedigree was consistent with autosomal recessive inheritance.

Other patients have been reported with similar stigmata of the EDS, who experienced serious ocular complications, and in whom there was considerable evidence to indicate a recessive mode of inheritance of the condition.

It is possible that there is a distinct ophthalmic form of the EDS, in which fragility of the ocular tissues predisposes to serious ophthalmological complications. 
I am grateful to Prof. V. A. McKusick for guidance during the preparation of this paper, and for permission to publish the case reports.

The author was supported by grants from the National Foundation for Birth Defects (CRCS-48) and the Arthritis and Rheumatism Council.

\section{References}

BANNERMAN, R. M., GRAF, c. J., and UPSON, J. F. (1967) Brit. med. F., 3, $55^{8}$

BARABAS, A. P. (1967) Ibid., 2, 612

Beighton, P. (1968a) "The Characteristics of the Ehlers-Danlos Syndrome”, p. 93-98. M.D.

Thesis, University of London

- (1968b) Brit. med. 7., 3, 409

-, PRICE, A., LORD, J., and Dickson, E. (1969) Ann. rheum. Dis., 28, 228

Bossu, A., and LAmBrechts, s. J. (1954) Ann. Oculist. (Paris), 187, 227

CAPOTORTI, L., and ANTONELli, M. (1966) Acta genet. med. (Roma), 15, 273

CORDELla, M., and vinciguerRA, E. (1966) Minerva oftal., 8, I03

DURHAM, D. G. (1953) A.M.A. Arch. Ophthal., 49, 220

FRANÇOIS, P., WOILlez, M., WARROT, and MAILlet, P. (1955) Bull. Soc. Ophtal. Fr., p. 392

FRIEDEN, J., HURWITt, E. S., and LEADER, E. (1962) Amer. F. Med., 33, 6 I 5

GRAF, C. J. (1965) Arch. Neurol. (Chicago), 13, 662

Johnson, s. A. M., and falls, H. F. (1949) Arch. Derm. Syph. (Chicago), 6o, 82

McKusick, v. A. (1966) "Heritable Disorders of Connective Tissue", 3rd ed., p. 179-229. Mosby,

St. Louis

Pemberton, J. W., freeman, H. m., and schepens, c. L. (1966) Arch. Ophthal. (Chicago), 76, 81 7

RONGHESe, F. (1936) Amer. F. Dis. Child., 5I, 1403

thomas, c., CORDIER, J., and Algan, B. (1952) Bull. Soc. belge Ophtal., no. I00, p. 375

-, Neimann, N., Cordier, J., and Algan, B. (1953) Bull. Soc. Ophtal. Fr., p. 2 I I

tOBIAS, N. (1934) Arch. Derm. Syph. (Chicago), 30, 540 